\title{
Effect of biological sprays on the incidence of grey mould, fruit yield and fruit quality in organic strawberry production
}

\author{
Soile Prokkola \\ MTT Agrifood Research Finland, Tutkimusasemantie 15, FI-92400 Ruukki, Finland. \\ Current address: Viinavuorentie 51, FI-91980 Lumijoki, Finland \\ Pirjo Kivijärvi \\ MTT Agrifood Research Finland, Plant Production Research, \\ Lönnrotinkatu 3, FI-50100 Mikkeli, Finland, \\ e-mail:pirjo.kivijarvi@mtt.fi
}

Plant diseases, especially grey mould (Botrytis cinerea), may cause severe losses in organic strawberry production. In a two-year period, 2001-2002, the effects of different biological sprays on grey mould, the fruit yield and fruit quality of organically grown strawberry 'Jonsok' were studied in field trials at MTT Agrifood Research Finland in Ruukki and Mikkeli. In Experiment 1 the biological sprays were seaweed, garlic and compost extracts, silicon and Trichoderma spp. on both trial sites. In Experiment 2, compost extract, Trichoderma spp. and Gliocladium catenulatum sprays were studied in Ruukki. The treatment time was chosen to control grey mould. The effect of different biological sprays on the incidence of grey mould and total and marketable yield was insignificant compared to the untreated control. In both years and in all trials the incidence of grey mould was low and rot occurred mainly in the latter part of the harvesting period, which may partly explain the small differences between treatments. Anyhow, despite of feasible biological control cultural control methods will be important to manage the fungus in organic strawberry production.

Key-words: Fragaria $\times$ ananassa, Botrytis cinerea, grey mould, organic cultivation, biological control, plant extracts, garlic extract, compost extract, seaweed, silicon, Trichoderma spp., Gliocladium catenulatum 
Prokkola, S. \& Kivijärvi, P. Effects of biological sprays on grey mould in organically grown strawberries

\section{Introduction}

Plant protection is a major problem in organic strawberry production. It has been estimated that in Finland the yield in organic strawberry production is $20-50 \%$ lower than in conventional production because of diseases and pests (Piirainen et al. 1999). Grey mould (Botrytis cinerea) is the disease, which causes the most severe losses in organic strawberry production. The incidence of grey mould varies annually depending on the weather conditions during flowering (Jarvis 1964). Average yield losses due to grey mould have been $3.7-27.5 \%$ in a number of organic or unsprayed trials depending on the cultivars and years. Potential yield losses in unsprayed fields can be as high as 55\% (Martinsson 1988). In organic cultivation the principal management methods for controlling grey mould are mostly based on the use of less susceptible cultivars and cultivation practices such as ensuring good aeration within the strawberry canopy.

Handbooks on organic farming recommend various biological sprays, e.g. plant extracts, compost extract, silicon and biocontrol agents for the control of pests and diseases (Lampkin 1990). According to Stephenson (1966), hydrolysed seaweed increased the yield and reduced the incidence of Botrytis infection of strawberries in three experiments. On other plants it controlled other diseases and some pests. Seaweed extract contains cytokinins, auxins, 1-aminocyclopropane-1-carbixylic acid and betaines, which can explain the many beneficial effects of seaweed on plants (Blunden 1991). Garlic (Allium sativum L.) is well known for its antimicrobial properties. In laboratory tests of 345 plant extracts, garlic extract was one of the most effective in inhibiting grey mould (Wilson et al. 1997). Garlic has also been mentioned as a pest repellent (Åkerberg 1997). Silica preparations are used to strengthen plant resistance physically against pests and diseases (Epstein 1994). Weltzien (1992) reported good control of grey mould by compost extract sprays in field experiments. The control effect is based on the high microbial activity of compost extract.

Many commercial products for biological control of grey mould are based on Trichoderma spp. BINAB ${ }^{\circledR} T F-W P$ and $B I N A B \circledR T$ Vector (Trichoderma polysporum ATCC 20475 and $T$. harzianum ATCC 20476) treatments were effective against grey mould on commercial strawberry farms in three European countries (Ricard and Jørgensen 2000).

Seaweed extract, garlic extract, compost extract, silica and sprays of Trichoderma spp. and Gliocladium sp. were investigated in organic strawberry production over a two-year period in field experiments at two research stations of MTT Agrifood Research Finland. The effects of biocontrol agents on the incidence of grey mould, fruit yield and fruit quality were studied.

\section{Material and methods}

\section{Establishment and management of field trials}

The effect of various biological treatments were studied in field trial (Experiment 1) in Mikkeli $\left(61^{\circ} 28^{\prime} \mathrm{N}, 27^{\circ} 18^{\prime} \mathrm{E}\right)$ and in two field trials (Experiment 1 and Experiment 2) in Ruukki $\left(64^{\circ} 41^{\prime} \mathrm{N}\right.$, $\left.25^{\circ} 05^{\prime} \mathrm{E}\right)$. In all the trials the fertilization and cultivation practices were in accordance with the regulations governing organic production in Finland.

Trials were established in fine sand soil. In Experiment 1 in Ruukki, 4 tons ha $^{-1}$ and in Mikkeli 5 tons ha $\mathrm{a}^{-1}$ of biotite $(5 \% \mathrm{~K}, 10 \% \mathrm{Mg})$ and at both experimental sites $500 \mathrm{~kg} \mathrm{ha}^{-1}$ of organic fertilizer (NPK 4-2-3) were broadcasted and tilled into the soil before planting. In Experiment 2, 5 tons ha ${ }^{-1}$ of dolomitic limestone and 27 tons ha $^{-1}$ of compost were added before planting. The extractable nutrient content of the fresh compost was $2.3 \mathrm{~kg}$ $\mathrm{N}, 0.84 \mathrm{~kg} \mathrm{P}, 2 \mathrm{~kg} \mathrm{~K}, 3.4 \mathrm{~kg} \mathrm{Ca}$ and $0.45 \mathrm{~kg} \mathrm{Mg}$ per ton. In spring 2001, wood ash was used at a rate of $300 \mathrm{~kg} \mathrm{ha}^{-1}$.

In Experiment 1, organically produced barerooted runner plants of 'Jonsok' were planted on raised beds in double rows $2.2 \mathrm{~m}$ apart, 12 plants per plot $45 \mathrm{~cm}$ apart in June 2000. Black plastic was used as mulch and a mixture of red 
Vol. 16 (2007): 25-33

fescue- sheep fescue was sown between the rows. The trial was established in a split-plot design replicated 4 times. The two trial sites represented the main plots. Experiment 2 was established in 1999 with conventionally produced runner plants of 'Jonsok' in single rows $1.3 \mathrm{~m}$ apart with $40 \mathrm{~cm}$ between plants. Mypex film was used as mulch with natural grass growing between the rows. The trial was established in a randomized complete block design with 6 replicates and 12 plants per plot. In all replicates the runner plants were of different origins.

The grass between the rows was cut with a lawn mower. Runners were removed in August. In 2001, dead leaves were brushed away in May, but not in 2002. Strawberry mites (Phytonemus pallidus) were controlled with predatory mites (Amplyseius cucumeris). In Ruukki, Galerucella sagittariae was controlled with pyrethrum (Bioruiskute $\mathrm{S} 0.5 \%$ ) twice in Experiment 1 and three times in Experiment 2 during the incidence of adult leaf beetles in both summers. Nets were used to protect the yield against birds.

\section{Spray treatments}

In Experiment 1 the biological sprays were 1\% (v/v) seaweed (Ascophyllum nodosum; Biolan Oy, Finland), garlic or compost extracts, $0.4 \%(\mathrm{v} / \mathrm{v})$ silicon solution (Si 7.7\%, Kekkilä Oy, Finland) or $0.1 \%$ (w/v) Trichoderma polysporum ATCC 20475 and T. harzianum ATCC 20476 (BINAB®TF-WP; Binab Bio-Innovation Ab, Sweden) supplemented with $0.2 \%(\mathrm{w} / \mathrm{v})$ sugar. In Experiment 2 the treatments were compost extract, Trichoderma spp. or $1 \%$ (w/v) Gliocladium catenulatum J1446 (Prestop; Kemira Oy, Finland). Spray treatments were the same in both 2001 and 2002. Non-treated plots served as control.

The commercial sprays were prepared and applied as recommended by the manufacturers. The garlic extract was prepared by mixing $10 \mathrm{~g}$ crushed organic garlic with 11 water $(1 \%$ $\mathrm{w} / \mathrm{v})$. Mixture was brewed for 2-5 days at room temperature. The compost extract was prepared according to Weltzien (1992). Composted organic cattle manure (composted for 9 months in outdoor conditions with straw, peat and sawdust, turned twice) was mixed with water in a ratio of 1:5 $(\mathrm{v} / \mathrm{v})$. The mixture was stirred once and kept at room temperature $\left(15-25^{\circ} \mathrm{C}\right)$ for $13-17$ days in an open vessel. The compost used in Ruukki and Mikkeli was of the same origin and lot in both years. In 2001 the $\mathrm{NH}_{4}-\mathrm{N}$ : $\mathrm{NO}_{3}-\mathrm{N}$ ratio $(2 \mathrm{M} \mathrm{KCl}$ extraction) of the compost was analysed, and in both years the phytotoxicity of compost was studied with cress (Lepidium sativum L.) seeds. Fifty seeds were sown in a Petri dish both on compost and horticultural peat (control) with 3 replicates. The seeds were incubated for 1 day at room temperature, and the number of germinated seeds and length of the roots were observed.

Both garlic and compost extracts were filtered and sprayed immediately without dilution. In Ruukki $G$. catenulatum was applied with a Hardi C-5-sprayer (pressure of 4 bar) and other treatments with an Alta 5000-sprayer (pressure of 3 bar). In Mikkeli sprays were applied with a Gardena 874-sprayer (pressure of 3 bar).

In 2001, the treatments were initiated 13 days before flowering in Ruukki and 8 days before flowering in Mikkeli, and were continued five times once a week, except $G$. catenulatum, which was applied four times. In Experiment 1, the average quantities of sprays used were $12 \mathrm{ml}$ and $16 \mathrm{ml}$ per plant in Mikkeli and Ruukki, respectively, and in Experiment $212 \mathrm{ml}$ per plant. The last applications were made six days before harvesting, except $G$. catenulatum in Experiment 2, which was applied 15 days before harvesting. In 2002, the treatments were initiated 8 days prior to flowering in Ruukki and 1 day prior to flowering in Mikkeli, and were continued weekly, four times in all treatments. In Experiment 1, the average quantities of sprays used were $25 \mathrm{ml}$ and $17 \mathrm{ml}$ per plant in Mikkeli and Ruukki, respectively, and 12 per plant in Experiment 2. The last treatments were applied 7 days before harvesting at both trial sites. 
Prokkola, S. \& Kivijärvi, P. Effects of biological sprays on grey mould in organically grown strawberries

\section{Experimental procedures and statistical analyses}

All plants were evaluated for winter injury. The beginning of flowering was recorded when more than $50 \%$ of plants in a plot had open flowers. The number of yield producing plants (more than 15 flowers per plant) was recorded during flowering. Strawberries were harvested twice a week during the fruiting season. The weight and number of marketable berries, small berries (undamaged, $\varnothing$ $<22 \mathrm{~mm}$ ), berries with grey mould, button berries (apical seediness) and other unmarketable berries (other disorders) were recorded, except in Mikkeli where the number of marketable berries was only partly counted in 2001 .

Statistical analysis of the data was carried out using the UNIVARIATE and GLM procedure of SAS (SAS Institute Inc., Gary, NC, USA). Percentages were arcsine-transformed prior to analysis. Mean comparisons were made using Tukey's studentized range test $(\mathrm{P}=0.05)$.

\section{Results}

\section{Grey mould}

In both years and in all trials the incidence of grey mould was low. In Experiment 1, in different treatments the average proportion of berries infected with grey mould ranged between 3.5 and $5.4 \%$ and between 1.8 and $2.7 \%$ of the total yield by weight in 2001 and 2002, respectively. In 2001 the incidence of grey mould was significantly higher in Ruukki than in Mikkeli. In Experiment 2, the incidence of grey mould was about the same as in Experiment 1 in 2001 and in 2002 even lower. The spraying treatments had no effect on the incidence of grey mould in any of the trials nor on the analysed percentages by weight or by number (Tables 1 and 2). In both years grey mould occurred mainly in the latter part of the harvesting periods, in the third and fourth week of harvest.

\section{Yields}

In Experiment 1 there were only small and nonsignificant differences in the average total and marketable yields between treatments or when the treatments were compared with the untreated control. In 2001, the average marketable yield was highest in the silicon spray treatment, $291 \mathrm{~g}$ per plant, and lowest in compost extract treatment, 256 g per plant. In the untreated control the average marketable yield was $281 \mathrm{~g}$ per plant. In 2002, the seaweed extract treatment gave the highest marketable yield, $423 \mathrm{~g}$ per plant, and the Trichoderma spp. treatment the lowest, $372 \mathrm{~g}$ per plant. The total and marketable yields were significantly higher and the size of marketable berries was larger in Ruukki than in Mikkeli in both years (Table 1).

In Experiment 2, the marketable yield analysed per yield-producing plant (more than 15 flowers per plant) was significantly higher in the Gliocladium treatment (430 g per plant) than in the Trichoderma treatment ( $319 \mathrm{~g}$ per plant). However, there existed no significant differences when the Trichoderma and Gliocladium treatments were compared with the untreated control. The average total yield, when calculated over all treatments was $447 \mathrm{~g}$ and $532 \mathrm{~g}$ per plant and the proportion of marketable yield was 80.5 and $78.0 \%$ in 2001 and 2002, respectively (Table 2).

\section{Unmarketable berries}

Berry size started to decrease in the middle of the harvest period. In 2001, treatments had no significant effect $(\mathrm{P}=0.05)$ on the proportion of small berries $(\varnothing<22 \mathrm{~mm})$ and button berries when compared to untreated control. The proportion of other disorders berries was significantly higher in Mikkeli than in Ruukki. In the seaweed and silicon treatments the proportion was significantly lower than in the Trichoderma spp. and garlic treatments and Trichoderma spp. treatment differed significantly from the untreated control. In 2002, button berries occurred significantly more in Mikkeli than 
Vol. 16 (2007): 25-33

Table 1 . The average strawberry total yield, marketable yield, unmarketable yield and berry size calculated by locations and treatments in Experiment 1. Unmarketable yield is presented by weight (w) or by berry number (n).

\begin{tabular}{|c|c|c|c|c|c|c|c|c|c|c|}
\hline \multirow[t]{2}{*}{ Year } & & & \multirow{2}{*}{$\begin{array}{l}\text { Total } \\
\text { yield } \\
\text { g/plant }\end{array}$} & \multirow{2}{*}{$\begin{array}{l}\text { Market- } \\
\text { able } \\
\text { yield } \\
\text { g/plant }\end{array}$} & \multicolumn{5}{|c|}{ Unmarketable yield ( $\%$ of total yield) } & \multirow{2}{*}{$\begin{array}{l}\text { Berry } \\
\text { size } \\
\mathrm{g}\end{array}$} \\
\hline & & & & & $\begin{array}{l}\text { Small } \\
\text { berries } \\
(<22 \mathrm{~mm}) \\
\text { (w) }\end{array}$ & $\begin{array}{l}\text { Grey } \\
\text { mould } \\
\text { (w) }\end{array}$ & (n) & $\begin{array}{l}\text { Button } \\
\text { berries } \\
\text { (w) }\end{array}$ & $\begin{array}{l}\text { Other } \\
\text { disorders } \\
\text { (w) }\end{array}$ & \\
\hline \multirow[t]{12}{*}{2001} & \multirow[t]{2}{*}{ Location } & Ruukki & $356^{\mathrm{a}}$ & $321^{\mathrm{a}}$ & $0.9^{b}$ & $5.4^{\mathrm{a}}$ & & 1.5 & $2.0^{b}$ & $11.3^{\mathrm{a}}$ \\
\hline & & Mikkeli & $296^{b}$ & $227^{b}$ & $9.5^{\text {a }}$ & $3.5^{b}$ & & 0.8 & $9.7^{\text {a }}$ & $7.9^{b}$ \\
\hline & \multirow[t]{10}{*}{ Treatment } & Control (nontreated) & 332 & 281 & 4.7 & 5.0 & & 1.0 & $5.1^{\mathrm{bc}}$ & 9.7 \\
\hline & & Trichoderma spp & 323 & 264 & 5.6 & 4.9 & & 1.0 & $7.4^{\text {a }}$ & 9.0 \\
\hline & & Compost extract & 303 & 256 & 5.3 & 3.5 & & 1.1 & $6.0^{\mathrm{abc}}$ & 9.3 \\
\hline & & Seaweed extract & 337 & 287 & 4.9 & 4.6 & & 1.2 & $4.6^{c}$ & 9.8 \\
\hline & & Silicon spray & 341 & 291 & 5.8 & 3.7 & & 1.2 & $4.9^{\mathrm{c}}$ & 10.2 \\
\hline & & Garlic extract & 319 & 263 & 4.8 & 5.0 & & 1.3 & $7.1^{\mathrm{ab}}$ & 9.6 \\
\hline & & F-test & & & & & & & & \\
\hline & & Treatment & NS & NS & NS & NS & & NS & $*$ & NS \\
\hline & & Location & $*$ & $* *$ & $* *$ & $* *$ & & NS & $* * *$ & $* * *$ \\
\hline & & Treatment $\mathrm{x}$ location & NS & NS & NS & NS & & NS & NS & NS \\
\hline \multirow[t]{11}{*}{2002} & \multirow[t]{2}{*}{ Location } & Ruukki & $572^{a}$ & $472^{a}$ & 6.7 & 2.7 & 3.7 & $1.0^{\mathrm{b}}$ & 7.1 & $9.2^{\mathrm{a}}$ \\
\hline & & Mikkeli & $451^{\mathrm{b}}$ & $314^{\mathrm{b}}$ & $19.1^{\mathrm{a}}$ & 1.8 & 2.9 & $3.4^{\mathrm{a}}$ & 6.2 & $8.5^{\mathrm{b}}$ \\
\hline & \multirow[t]{9}{*}{ Treatment } & Control (nontreated) & 501 & 384 & 14.0 & 2.3 & 3.4 & $1.8^{\mathrm{ab}}$ & 6.3 & 8.8 \\
\hline & & Trichoderma spp & 491 & 372 & 13.7 & 2.0 & 2.8 & $3.2^{\mathrm{a}}$ & 6.4 & 8.7 \\
\hline & & Compost extract & 508 & 381 & 12.7 & 2.3 & 3.0 & $2.9^{\mathrm{ab}}$ & 7.6 & 9.0 \\
\hline & & Seaweed extract & 542 & 423 & 12.7 & 2.2 & 3.5 & $1.9^{\mathrm{ab}}$ & 6.4 & 9.0 \\
\hline & & Silicon spray & 531 & 415 & 10.3 & 2.3 & 3.2 & $2.2^{\mathrm{ab}}$ & 7.0 & 8.7 \\
\hline & & Garlic extract & 498 & 385 & 13.5 & 2.6 & 3.5 & $1.3^{\mathrm{b}}$ & 6.3 & 8.9 \\
\hline & & F-test & NS & NS & NS & NS & NS & $*$ & NS & NS \\
\hline & & Location & $*$ & $* *$ & $* *$ & NS & NS & $* * *$ & NS & $*$ \\
\hline & & Treatment $\mathrm{x}$ location & NS & NS & NS & NS & NS & NS & NS & NS \\
\hline
\end{tabular}

${ }^{\text {a-c }}$ Annual means (year 2001 or 2002) within the same column and location or treatment not sharing the same letter differ significantly (Tukey, $\mathrm{P}=0.05$ )

in Ruukki and the proportion of button berries measured by weight was significantly higher in the Trichoderma treatment than in the garlic extract treatment. In the grading class other disorders there existed no differences between trial sites or between treatments (Tables 1 and 2).

\section{Maturity of compost}

In 2001, the $\mathrm{NH}_{4}-\mathrm{N}$ and $\mathrm{NO}_{3}-\mathrm{N}$ contents $(2 \mathrm{M}$ $\mathrm{KCl}$ extraction) of the compost used for the compost extract were 47.05 and $0.28 \mathrm{mg} \mathrm{l}^{-1}$ compost, respectively. In both years the compost decreased 
Prokkola, S. \& Kivijärvi, P. Effects of biological sprays on grey mould in organically grown strawberries

Table 2. The average strawberry total yield, marketable yield, unmarketable yield and berry size calculated by years and treatments in Experiment 2 in Ruukki. Unmarketable yield is presented by weight (w) or by berry number (n). Yielding plant: more than 15 flowers per plant.

\begin{tabular}{|c|c|c|c|c|c|c|c|c|c|}
\hline & & \multirow{3}{*}{$\begin{array}{l}\text { Total yield } \\
\text { g/yielding } \\
\text { plant }\end{array}$} & \multirow{3}{*}{$\begin{array}{c}\text { Marketable } \\
\text { yield } \\
\text { g/yielding } \\
\text { plant }\end{array}$} & \multicolumn{5}{|c|}{ Unmarketable yield (\% of total yield) } & \multirow{3}{*}{$\begin{array}{c}\text { Berry size } \\
\mathrm{g}\end{array}$} \\
\hline & & & & \multirow{2}{*}{$\begin{array}{c}\text { Small berries } \\
(<22 \mathrm{~mm}) \\
(\mathrm{w})\end{array}$} & \multicolumn{2}{|c|}{ Grey mould } & \multirow{2}{*}{$\begin{array}{c}\text { Button } \\
\text { berries } \\
\text { (w) }\end{array}$} & \multirow{2}{*}{$\begin{array}{c}\text { Other } \\
\text { disorders } \\
\text { (w) }\end{array}$} & \\
\hline & & & & & (w) & (n) & & & \\
\hline Year & 2001 & 447 & 360 & $7.4^{\mathrm{b}}$ & $5.5^{\mathrm{a}}$ & $9.3^{\mathrm{a}}$ & 3.6 & 3.2 & 8.6 \\
\hline & 2002 & 532 & 415 & $14.0^{\mathrm{a}}$ & $0.6^{\mathrm{b}}$ & $0.9^{\mathrm{b}}$ & 3.9 & 4.3 & 8.3 \\
\hline \multirow[t]{8}{*}{ Treatment } & \multirow{4}{*}{$\begin{array}{l}\text { Control } \\
\text { Trichoderma } \\
\text { spp. } \\
\text { Gliocladium sp. } \\
\text { Compost extract }\end{array}$} & 496 & $394^{a b}$ & 10.7 & 3.4 & 5.4 & 4.6 & 2.8 & $8.5^{\mathrm{ab}}$ \\
\hline & & 410 & $319^{b}$ & 10.4 & 2.9 & 4.7 & 4.2 & 4.1 & $8.1^{\mathrm{b}}$ \\
\hline & & 542 & $430^{\mathrm{a}}$ & 10.5 & 3.4 & 5.7 & 3.3 & 4.1 & $8.7^{\mathrm{a}}$ \\
\hline & & 511 & $408^{a b}$ & 11.0 & 2.5 & 4.6 & 2.8 & 3.9 & $8.5^{\mathrm{ab}}$ \\
\hline & \multicolumn{9}{|l|}{ F-test } \\
\hline & Treatment & NS & $*$ & NS & NS & NS & NS & NS & $*$ \\
\hline & Year & NS & NS & $* *$ & $* * *$ & $* * *$ & NS & NS & NS \\
\hline & Treatmet x year & NS & NS & NS & NS & NS & NS & NS & NS \\
\hline
\end{tabular}

a-b Means within the same column and year or treatment not sharing a common letter differ significantly (Tukey, $\mathrm{P}=$ $0.05)$

the germination and root growth of cress (Lepidium sativum L.) seeds. In 2001, the germination percentages were 92 and $86 \%$ in the control and compost, respectively, and in 200299 and $82 \%$. The root growth in compost was $55 \%$ of that in the control in 2001 and $39 \%$ in 2002 .

\section{Discussion}

Grey mould infection of berries results in most cases from infection of the floral parts resulting in latent infection of the receptacles. The effects of this are not seen until the fruit ripen (Jarvis and Borecka 1968). Biological sprays were studied primarily to control grey mould, and treatments were done during bloom to provide acceptable control. Anyhow, in our field trials the incidence of grey mould was low, which may be one reason for non significant differences between treatments. The removal of leaf litter in 2001 could be one reason for low incidence of grey mould, since dead leaves are the principal inoculum source at the time of flowering (Braun and Sutton 1987). The weather conditions prevailing during flowering affect the incidence of grey mould on fruits (Bulger et al. 1987). In 2001 and 2002 in Ruukki and in 2002 in Mikkeli the precipitation was low at the beginning of flowering period, so the weather conditions were unfavourable for grey mould infection. The susceptibility of 'Jonsok' to B. cinerea is medium (Daugaard 1999). Perhaps a quite resistant cultivar was one reason for low grey mould infection.

Although the incidence of grey mould tends to increase over the years of perennial cultivation (Balázs 1974, Birkeland et al. 2002), in 2001 in Ruukki, no differences were observed in the incidence of grey mould between the younger (Experiment 1) and the older (Experiment 2) field trials. In 2002, even less grey mould was observed in the older trial. In Experiment 1, the plants were placed in double rows and in Experiment 2 in single rows. According to Legard et al. (2000), spacing has a dramatic effect on the incidence of grey mould. In organic farming a single-row system is generally recommended (Daugaard 1999).

In earlier studies control of grey mould has been obtained with seaweed (Stephenson 1966), compost extract (Weltzien 1992) and with Tricho- 


\section{AGRICULTURAL AND FOOD SCIENCE}

Vol. 16 (2007): 25-33

derma spp. (Ricard and Jørgensen 2000). In our field trials rot was more common at the end of the harvest period, which may be one reason for non- significant differences between treatments. According to Svensson (1996) and Ricard and Jørgensen (2000), both Trichoderma spp. and chemical control sprayings during flowering have shown decreasing effects on Botrytis rot towards the end of the harvesting period. The period from flowering to first harvest lasted 20 days in Ruukki and 26-27 days in Mikkeli. In our study Trichoderma spp. was applied as a spray. According to Kovach et al. (2000) T. harzianum gave better Botrytis control when delivered by bumble bees or honey bees than applied as a spray. Also in official pesticide trials in Finland three or four Binab TF WP spray treatments did not affect the incidence of grey mould on 'Senga Sengana' significantly in 2001 and 2002 (Laine 2001, 2002).

In our trials cattle manure compost extract had no significant effect to grey mould or yield level. Weltzien (1992) reported contrary results. Five treatments with cattle manure compost extract indicated significant control $(67 \%)$ of grey mould on strawberries and a significant yield increase in a field experiment. Possible differences in the compost extracts may have resulted from differences in the composting methods and maturity of compost. In Germany the manure-straw mixture was amended with about $15 \%$ field soil or old compost. The compost piles were not turned, and composting time was about six months (Weltzien 1992). In Finland the composting process during winter is probably slower than in Germany due to the colder climate. The compost was not amended with soil and the compost pile was turned, contrary to what was done in Germany. Although the compost appeared mature, $\mathrm{NH}_{4}-\mathrm{N}: \mathrm{NO}_{3}-\mathrm{N}$ ratio was 168 in 2001. The recommended ratio for mature compost is below one (Tontti and Mäkelä-Kurtto 2000). In both years the compost decreased the percentage of germination and root growth of cress compared to the peat control, indicating that the compost was not mature. In order to induce suppression of plant diseases, compost has to be mature and stable (Hoitink et al. 1997). Since the control properties of compost extract are largely based on microbes, the composting process and raw materials may affect the efficacy.

In our trials some biological treatments increased yields slightly compared to untreated control, but differences were not significant. The proportion of unmarketable berries was $9.8-30.5 \%$ depending on the trial site and year. The unmarketable berries were mostly small berries, because berry size of 'Jonsok' tends to become smaller quite early during the harvesting period. In the class other disorders some differences between treatments were observed in 2001, reflecting the fact that the sprays may have some effect on the pests (e.g. Galerucella sagittariae) causing damage in this class. Capsids (plant bugs) cause a severe malformation of the receptacle referred to as 'button berries' or 'apical seediness' (Handley and Pollard 1993). Of the capsids the European tarnished plant bugs are the most common in Finnish strawberry fields (Tuovinen and Tolonen 2002). In our study the treatments had no effect on the proportion of button berries compared to the control. Apical seediness of strawberry fruits may also be caused by frost injury (Maas 1998). In Mikkeli there was frost at the beginning of flowering in 2001, but it had no effect on the proportion of button berries at the beginning of harvest. The yield level of our trials was comparable to yields of 'Jonsok' in conventional cultivation in variety trials (Hietaranta and Matala 2002) and on berry farms (Matala and Tuovinen 2003).

Our study showed that resistant variety, cultural methods and weather conditions may affect the incidence of $B$. cinerea, and may have positive effect on the control of grey mould. However, due to climatic and epidemic variations, satisfactory control of grey mould may be hard to achieve by cultural methods in every year. Therefore in organic strawberry production biological control of $B$. cinerea need to be develop and should be a supplement to cultural and sanitation (removal of diseased leaves and berries) methods.

Acknowledgements. This paper is an outcome of the project Developing cultivation technique of organically grown strawberry, which was financially supported by the Finnish Ministry of Agriculture and Forestry. 


\section{AGRICULTURAL AND FOOD SCIENCE}

Prokkola, S. \& Kivijärvi, P. Effects of biological sprays on grey mould in organically grown strawberries

\section{References}

Åkerberg, C. 1997. Växtskyddsmedel i ekologisk odling. Regler, preparat, erfarenheter. Jordbruksinformation $\mathrm{nr} 6$. Jordbruksverket. 32 p. ISSN 1102-8025.

Balázs, K. 1974. Connection between the Botrytis cinerea infection and yield of strawberry. Növényvédelmi Kutató Intézet Közleményei 8: 211-230.

Birkeland, L., Døving, A. \& Sønsteby, A. 2002. Yield and quality in relation to planting bed management of organically grown strawberry cultivars. Acta Horticulturae 567: 519-522.

Blunden, G. 1991. Agricultural uses of seaweeds and seaweed extracts. In: Guiry, M. \& Blunden, G. (eds.). Seaweed resources in Europe. p. 65-81.

Braun, P.G. \& Sutton, J.C. 1987. Inoculum sources of Botrytis cinerea in fruit rot of strawberries in Ontario. Canadian Journal of Plant Pathology 9: 1-5.

Bulger, M.A., Ellis, M.A. \& Madden, L.V. 1987. Influence of temperature and wetness duration on infection of strawberry flowers by Botrytis cinerea and disease incidence of fruit originating from infected flowers. Phytopathology 77 : 1225-1230.

Daugaard, H. 1999. Cultural methods for controlling Botrytis cinerea Pers. in strawberry. Biological Agriculture and Horticulture 16: 351-361.

Epstein, E. 1994. The anomaly of silicon in plant biology. Proceedings of the National Academy of Science USA 91: 11-17.

Handley, D.T. \& Pollard, J.E. 1993. Tarnished plant bug (Lygus lineolaris) behaviour on cultivated strawberries. Acta Horticulturae 348: 463-468.

Hietaranta, T. \& Matala, V. 2002. Preliminary variety trials in Finland: identifying promising strawberry varieties for further testing. Acta Horticulturae 567: 211-214.

Hoitink, H.A.J., Srone, A.G. \& Han, D.Y. 1997. Suppression of plant diseases by composts, HortScience 32, 2: 184-187.

Jarvis, W.R. 1964. The effect of some climatic factors on the incidence of grey mould of strawberry and raspberry fruit. Horticultural Research 3: 65-71.

Jarvis, W.R. \& Borecka, H. 1968. The susceptibility of strawberry flowers to infection by Botrytis cinerea Pers. ex Fr. Horticultural Research 8: 147-154.

Kovach, J., Petzoldt, R. \& Harman, G.E. 2000. Use of honey bees and bumble bees to disseminate Trichoderma harzianum 1295-22 to strawberries for Botrytis control. Biological control 18: 235-242.

Laine, P. 2001. Strawberry trials. In: Ketola, J. et al. (eds.). Trial report fungicides and insecticides. Jokioinen: MTT Agrifood Research Finland. p. 130-134.
Laine, P. 2002. Strawberry trial. In: Ketola, J. et al. (eds.). Trial report fungicides and insecticides. Jokioinen: MTT Agrifood Research Finland. p. 136-140.

Lampkin, N. 1990. Organic farming. Farming press. UK.

Legard, D.E., Xiao, C.L., Mertely, J.C. \& Chandler, C.K. 2000. Effects of plant spacing and cultivar on incidence of Botrytis fruit rot in annual strawberry. Plant Disease 84: 531-538.

Maas, J.L. 1998. Compendium of strawberry diseases. The American Phytopathological Society. APS Press. Second edition. $98 \mathrm{p}$.

Martinsson, M. 1988. Alternativodling av jordguppar. Lantbruksnämden i Blekinge län. Karlskrona, p. 1-12.

Matala, V. \& Tuovinen, T. 2003. Mansikan lajikekokeet käytännön viljelmillä: kokeiden perustaminen 1999 ja satovuosien 2000, 2001 ja 2002 tulokset. Abstract: Strawberry variety trials on berry farms. Agrifood Research Working papers 26. 33 p. Available on the Internet: http://www.mtt.fi/mtts/ $\mathrm{pdf} / \mathrm{mtts} 26 . \mathrm{pdf}$

Piirainen, A., Nissinen, A. \& Kurppa, S. 1999. Ympäristötuen mukaisen seurantajärjestelmän ja ekologisen tuholaistorjunnan kehittäminen luomutuotannossa (LUOMUKAS). loppuraportti. $33 \mathrm{p}$.

Ricard, T. \& Jørgensen, H. 2000. BINAB's effective, economical, and environment compatible Trichoderma products as possible Systemic Acquired Resistance (SAR) inducers in strawberries. DJF-rapport 12: 67-75.

Stephenson, W.M. 1966. The effect of hydrolysed seaweed on certain plant pests and diseases. In: Young, E.G. \& McLachlan, J.L. (eds.). Proceedings of International Seaweed Symposium 5, 1965. p. 405-415.

Svensson, B. 1996. Gråmögelbekämpning i jordgubbar - finns det alternativ? Frukt- och Bärodling 38, 2: 54-56, 58.

Tontti, T. \& Mäkelä-Kurtto, R. 2000. Proposal for new quality criteria for composting and composts in Finland. In: Proceedings of the International Composting Symposium. Truro: CBA Press. p. 622-624.

Tuovinen, T. \& Tolonen, T. 2002. Arthropod biodiversity on conventional and organic strawberry. Acta Horticulturae 567: 663-666.

Weltzien, H.C. 1992. Biocontrol of foliar fungal diseases with compost extracts. In: Andrews, J.H. \& Hirano, S.S. (eds.) Microbial ecology of leaves. Springer-Verlag, New York. p. 430-450.

Wilson, C.L., Solar, J.M., El Ghaouth, A. \& Wisniewski, M.E. 1997. Rapid evaluation of plant extracts and essential oils for antifungal activity against Botrytis cinerea. Plant Disease 81: $204-210$ 


\title{
SELOSTUS
}

\section{Biologisten ruiskutteiden vaikutus harmaahomeen esiintymiseen, satoon ja sadon laatuun luomumansikan viljelyssä}

\author{
Soile Prokkola ja Pirjo Kivijärvi \\ MTT Kasvintuotannon tutkimus
}

\begin{abstract}
Kasvitaudit, erityisesti harmaahome (Botrytis cinerea), aiheuttavat luomumansikalle huomattavia satotappioita. Niinpä Maa- ja elintarviketalouden tutkimuskeskuksessa (MTT) tutkittiin biologisten ruiskutteiden vaikutuksia harmaahomeen esiintymiseen sekä sadon määrään ja laatuun luomumansikan viljelyssä. Kokeet suoritettiin Ruukissa ja Mikkelissä vuosina 2001-2002. Mansikkakasvustot käsiteltiin merileväruiskutteella, valkosipuliuutteella, kompostiuutteella, piiruiskutteella tai Trichoderma spp. -ruiskutteella. Ruukin toisessa kokeessa mansikat käsiteltiin kompostiuutteella, Trichoderma spp. - tai Gliocladium catenulatum -ruiskutteilla. Ruiskutettuja ruutuja verrattiin ruiskuttamattomiin ruutuihin. Ruiskutusajankohdat valittiin harmaahomeen torjunnan mukaisesti, ja koelajikkeena oli Jonsok.
\end{abstract}

Biologiset ruiskutteet eivät vaikuttaneet harmaahomeen esiintymiseen, sadon määrään ja pienten marjojen, nappipäisten marjojen sekä muutoin vioittuneiden marjojen osuuteen sadossa ruiskuttamattomaan käsittelyyn verrattuna. Joitakin eroja kuitenkin löytyi eri ruiskutuskäsittelyjen välillä. Kokeista saadut taimikohtaiset satomäärät olivat kuitenkin samaa suuruusluokkaa kuin tilakokeissa tavanomaisilta viljelyksiltä saadut Jonsok-lajikkeen sadot. Kokeiden perusteella voidaan päätellä, että varsinaisten torjuntatoimenpiteiden lisäksi lajikevalinta, sääolot ja viljelymenetelmät vaikuttavat harmaahomeen esiintymiseen mansikkakasvustossa. 